\title{
Study of Metal Adsorbent Prepared from Tur Dal (Cajanus cajan) Husk: A Value Addition to Agro-waste
}

\author{
Vishal.R.Parate ${ }^{1}$, Mohammed.I.Talib ${ }^{2}$ \\ ${ }^{1}$ (Department of Food Technology, University Institute of Chemical Technology, North Maharashtra University, \\ Jalgaon, India) \\ ${ }^{2}$ (Department of Food Technology, University Institute of Chemical Technology, North Maharashtra University, \\ Jalgaon, India)
}

\begin{abstract}
The aim of the present investigation was to develop metal adsorbent from agro-waste (husk) of tur dal (Cajanus cajan) for their value addition and to improve the effectiveness of developed adsorbent by optimizing the conditions of adsorption for complete removal of Cu ions from its $50 \mathrm{ml}, 50 \mathrm{ppm}$ solution. The washed and dried tur dal husk was carbonized in air tight container at $500{ }^{\circ} \mathrm{C}$ for $1 \mathrm{hr}$. to get its carbon form possessing adsorption property. The physicochemical characterization of prepared adsorbent was done for yield, bulk density, conductivity, particle size, moisture, ash, water soluble content, pH, calorific value, trace elements, crystal nature and structural morphology. The optimum parameters for adsorption was studied by varying $\mathrm{pH}(2-10)$, agitation speed $(50-250 \mathrm{rpm})$, temperature $\left(10-60{ }^{\circ} \mathrm{C}\right)$, adsorbent dose $(0.25-2.75 \mathrm{~g})$ and contact time (0.5-4 hr.). The study concludes tur dal husk can be exploited for the preparation of metal adsorbent. The prepared adsorbent was found to be most effective in an adsorption condition of $6 \mathrm{pH}, 150 \mathrm{rpm}$ agitation speed, $60{ }^{\circ} \mathrm{C}$ temperature, $2.75 \mathrm{~g}$ adsorbent dose and $3 \mathrm{hr}$. contact time. The thermodynamic study revealed adsorption by the developed adsorbent was endothermic (positive $\Delta \mathrm{H}^{0}$ ), non spontaneous (positive $\Delta \mathrm{G}^{0}$ ) and increasing randomness at the adsorption sites (positive $\Delta \mathrm{S}^{0}$ ).
\end{abstract}

Keywords: Adsorption, copper, optimization, thermodynamic, tur dal husk

\section{Introduction}

Toxic heavy metal ions are being added to the aquatic streams by means of various industrial activities at much higher concentration than the prescribed limits, possessing a serious threat to aquatic life and leading to the environmental degradation [1]. The conventional methods (ultra filtration, reverse osmosis, chemical precipitation, ion exchangers etc.) to remove metal ions from aqueous solutions however are not much preferable many times due to their own limitations such as production of sludge, less efficiency, high cost [2]. Adsorption process is considered better as compared to various available water pollution control technologies, because of convenience, ease of operation and simplicity of design. Adsorption is nothing but the accumulation of a substance at the interface solid and liquid or solid and gas. Adsorbate is the substance that accumulates at the interface ,and the solid on which adsorption occurs is known as adsorbent. The adsorption mainly occurs due to the unbalanced forces (van der Waals, electrostatic) at the surface of the solids [3].

Efficient and environment friendly adsorbents are still in high demand which reduces heavy metal content in waste water to acceptable level at affordable costs. The researchers are always in search for low-cost adsorbents, to be prepared from a wide variety of raw materials which can be easily activated, cheap, abundant, having low inorganic content and high organic (carbon) content. Living microorganisms or dead biomass of microorganisms and agricultural waste can be used as biosorbents. The use of living microorganism as biosorbent however has practical limitations as their growth is inhibited when the significant amount of metal ions are absorbed by microorganisms or when the concentrations of metal ions are high. Plant wastes are inexpensive as they have no or very low economic value. Abundant waste materials or products from industrial and agricultural activities can be potential alternatives for heavy metal removal [4,5].The use of agricultural residues as biosorbent is therefore receiving considerable attention as large quantities are readily and cheaply available as a byproduct of various industries, economic and eco-friendly due to their unique chemical composition, renewable and more efficient [6,7].Agro-waste basically composed of cellulose and lignin along with other components like water, starches, hemicelluloses, simple sugars, proteins, some lipids, extractives (low molecular organic substances soluble in neutral solvent), resin of terpenes, fat, waxes, fatty acids, alcohols, tannins, flavonoides, colour pigments, low molecular weight hydrocarbons, ash and many other compounds which carries a variety of functional groups having capability of complexing heavy metal ions which facilitate their removal by adsorption. The functional group present in the agro-biomass are acetamido, alcoholic, carbonyl, hydroxyl, carboxyl, phenolic, ether, amido, amino, sulphydryl, phosphoryl, esters, lactones, structural polysaccharides and many [8-10]. Cassava waste [11], tamarind wood [12], waste tea leaves [13], banana and 
orange peels [14], olive stone waste [15], walnut shell [16],soybean hulls [17] and various other ago-waste in their raw form have been studied extensively and found suitable for metal removal.

The application of raw agricultural waste or untreated plant wastes as adsorbents however reported to have low adsorption capacity due to low surface area and porosity $[18,19]$. The plant wastes need to be modified or treated to boost its performance before being applied for the decontamination of heavy metals [20]. The processing of agro-waste for their modification into carbon form is needed as in this form the agro-waste possesses high porosity and large surface area making it more effective for metal adsorption process [21].

Tur dal (Cajanus cajan) husk which is about 8 percent of the pulse grain and is the low cost byproduct or waste of pulse processing industry. The husk of tur dal is reported to contain about 5.6 percent crude protein, 0.3 percent fat, 31.9 percent crude fiber, 3.5 percent ash and 58.7 percent carbohydrates and posses potential to be used as metal adsorbent [22]. Merely throwing Tur dal husk for cattle feed is the wasteful way of utilizing this material. As tur dal husk have no or little value and available in large quantity, it is better to do some effort for their value addition. It would be an act of value addition if tur dal husk are converted into their carbon form and utilize as adsorbent for heavy metals removal. The conversion of tur dal husk into adsorbent carbon also help in reducing the cost of waste disposal o this material and provide a potentially inexpensive alternative to the existing commercial activated carbon [23, 24]. Very few researchers have studied the metal adsorption ability of dal husk (Black gram, Bengal gram, Lathyrus sativus) [25, 26]. N. Ahalya, et al., investigated raw husk of tur dal (Cajanus Cajan) as a new biosorbent for the removal of Ferric (III) and Chromium (VI) ions from aqueous solutions. However the carbon form of tur dal husk is still not prepared and investigated for metal adsorption purpose.

The aim of present work was to optimize the condition of copper ion adsorption from its solution by adsorbent carbon prepared from tur dal husk for value addition to ago-waste.

\section{Materials And Methods}

The tur dal husk waste was obtained from local pulse processing industry Niki Agro Products Pvt. Ltd, M.I.D.C, Jalgaon, Maharashtra state, India. A copper (II) ion stock solution was prepared by dissolving appropriate amount of copper sulfate in double distilled water. The analytical grade chemicals of standard brand were procured from local chemicals supplier and used for analysis purpose.

\subsection{Preparation of Metal Adsorbent from Tur Dal Husk}

The metal adsorbent from the Tur dal husk was prepared by slight modification in method described by E.-S.Z. El-Ashtoukhya et al., 2008 [27].The obtained husk waste was first washed with tap water repeatedly to remove dirt and other particulate matter and then with double distilled water. The washed husk was subjected for drying in hot air oven at 105 degree centigrade for six hours. The dried material was then cooled and gently ground in a grinder ground husks were then subjected to carbonization in an air tight stainless steel container by heating in muffle furnace at 500 degree centigrade for one hour. The produced carbonized material was cooled and washed with 0.1 molar hydrochloric acid to remove ash. The acid washed material was then drained with double distilled water until the $\mathrm{pH}$ of the filtrate reached above 5.0 and again dried at 105 degree centigrade for 6 hours in hot air oven. The material ultimately was gently crushed and sieved to particle size ranging 0.25 0.15 millimeter and stored in air tight container. The prepared adsorbent was referred as $\mathrm{Ad}_{1}$ for further study for the adsorption of copper ion. The yield of $\mathrm{Ad}_{1}$ was calculated as follows given in equation 1:

$$
\text { Yield }=\frac{\mathrm{Wc}}{\mathrm{Wo}_{\mathrm{O}}} \times 100
$$

Where, $\mathrm{W}_{\mathrm{o}}=$ Mass of the original material before carbonization, and $\mathrm{W}_{\mathrm{c}}=$ Mass of the material remaining after carbonization.

\subsection{Characterization of Adsorbent}

The $\mathrm{Ad}_{1}$ was analysed for various physicochemical parameters such as bulk density and ash as per CEFIC (European Chemical Industry Council) methods [28]. Bulk Density apparatus (DBK 5028-7) was used in the analysis of density. The particle size, moisture, water soluble content and $\mathrm{pH}$ was analysed based on Bureau of Indian Standards method IS 877: 1989 [29].Electrical conductivity was determined by IS 14767: 2000 method [30] using Conductivity Meter of Systronic (Model 304). Calorific value of adsorbent sample was estimated using Digital Bomb Calorimeter (Rajdhani Scientific, Model: RSB 6). The traces of elements in adsorbent were determined using Inductively Coupled Plasma Optical Emission Spectrometer (ICP-OES), Model: VARIAN 720-ES. The presence of carbon in the prepared adsorbent and nature and shape of its crystals was confirmed by X-Ray Diffraction (XRD), performed in a XRD of BRUKER (Germany), Model: D8 ADVANCE with scintillation detector. The morphological study of raw husk and $\operatorname{Ad}_{1}$ was carried out by 
Scanning Electron Microscope (SEM) of HITACHI (Model: S-4800,TypeII)coupled with Energy Dispersive Xray Spectroscopy (EDS) of BRUKER.

\subsection{Preliminary Adsorption Study}

Initially the rough trial was taken to check whether prepared adsorbent $\left(\mathrm{Ad}_{1}\right)$ remove $\mathrm{Cu}$ ion from its solution or not. The batch adsorption was carried out under the conditions given in Table 1. The appropriate amount of $\mathrm{Cu}$ solution and adsorbent was taken in $100 \mathrm{ml}$ capped conical flasks and agitated in Orbital Shaking Incubator (REMI) for $0.5,1,1.5,2,2.5,3,3.5,4,4.5,5,5.5,6,6.5,7,7.5$ and $8 \mathrm{hr}$. providing sufficient time to establish equilibrium. After each contact period the suspension was filtered through Whatman No.42 filter paper to separate the suspension of $\mathrm{Ad}_{1}$ and the $\mathrm{Cu}$ solution. The filtrate was then diluted to appropriate dilution with double distilled water for the analysis of residual $\mathrm{Cu}$ concentration using Atomic Absorption Spectrophotometer (SL 176, ELICO Ltd., Hyderabad, India). The \% Removal or Adsorption of $\mathrm{Cu}$ was calculated as follows shown in equation 2 :

$$
\% \text {.Removal }=\left\{\frac{\mathrm{C}_{\mathrm{i}}-\mathrm{C}_{\mathrm{e}}}{\mathrm{C}_{\mathrm{i}}}\right\} \times 100
$$

Where, $C_{i}$ is initial concentration of heavy metals ions and $\mathrm{Ce}$ is final or equilibrium concentration of heavy metal ion in milligram per liter [31].

Table 1: Initial Adsorption Trial

\begin{tabular}{|l|c|c|c|}
\hline \multicolumn{1}{|c|}{ Batch Parameter } & First Trial & Second Trial & Third Trial \\
\hline Concentration of Cu ion solution & $100 \mathrm{ppm}$ & $50 \mathrm{ppm}$ & $50 \mathrm{ppm}$ \\
\hline Volume of Cu ion solution & $50 \mathrm{ml}$ & $50 \mathrm{ml}$ & $50 \mathrm{ml}$ \\
\hline $\mathrm{pH}$ of Cu ion solution & $5.63(\mathrm{Natural})$ & $5.78(\mathrm{Natural})$ & $5.78(\mathrm{Natural})$ \\
\hline Adsorbent dose & $0.1 \mathrm{~g}$ & $0.1 \mathrm{~g}$ & $0.25 \mathrm{~g}$ and $0.5 \mathrm{~g}$ \\
\hline Particle size of Adsorbent & $0.25-0.15 \mathrm{~mm}$ & $0.25-0.15 \mathrm{~mm}$ & $0.25-0.15 \mathrm{~mm}$ \\
\hline Agitation speed & $150 \mathrm{rpm}$ & $150 \mathrm{rpm}$ & $150 \mathrm{rpm}$ \\
\hline Temperature & $30{ }^{\circ} \mathrm{C}$ & $30{ }^{0} \mathrm{C}$ & $30^{\circ} \mathrm{C}$ \\
\hline Contact Time & $\begin{array}{c}0.5-8 \mathrm{hr} . \\
\text { (with time interval } 0.5 \mathrm{hr} \text {.) }\end{array}$ & $\begin{array}{c}0.5-8 \mathrm{hr} . \\
\text { (with time interval } 0.5 \mathrm{hr} \text {.) }\end{array}$ & (with time interval $0.5 \mathrm{hr}$.) \\
\hline
\end{tabular}

\subsection{Optimization of Adsorption Condition}

Based on the result of initial trial the batch adsorption study was planned for the optimization of $\mathrm{pH}$, agitation speed, temperature and adsorbent dose, keeping the other parameter of adsorption such as initial concentration of $\mathrm{Cu}$ solution $(50 \mathrm{ppm})$, volume of solution $(50 \mathrm{ml})$, particle size $(0.25-0.15 \mathrm{~mm})$ and contact time (4 hr.) constant. The $\mathrm{pH}$ optimization study was carried out by varying $\mathrm{pH}$ by 1 from 2 to $10 \mathrm{pH}$, keeping agitation speed $150 \mathrm{rpm}$, temperature $30{ }^{\circ} \mathrm{C}$ and adsorbent dose $0.5 \mathrm{gram}$. The $\mathrm{pH}$ of solutions was maintained using 0.1-0.5 M solution of $\mathrm{HCl}$ or $\mathrm{NaOH}$. After agitation of mixture the suspension was filtered and filtrate analysed for residual $\mathrm{Cu}$ ion concentration. In the optimization of agitation speed the agitation speed varied from 50- $250 \mathrm{rpm}$ keeping $\mathrm{pH}$ at optimized level, temperature at $30{ }^{\circ} \mathrm{C}$ and adsorbent dose $0.5 \mathrm{gram}$. The optimized condition of temperature was obtained by changing temperature from $10{ }^{\circ} \mathrm{C}$ to $60{ }^{\circ} \mathrm{C}$ while keeping $\mathrm{pH}$ and agitation speed at optimized level and adsorbent dose 0.5 gram. The valuable information on the mechanism of adsorption is provided by thermodynamic analysis. Thermodynamic studies were therefore carried out to evaluate the feasibility of the adsorption process by estimating the standard Gibb's free energy $\left(\Delta \mathrm{G}^{0}\right)$, enthalpy change $\left(\Delta \mathrm{H}^{0}\right)$ and entropy change $\left(\Delta \mathrm{S}^{0}\right)$.

The $\Delta \mathrm{G}^{0}$ in $\mathrm{J} / \mathrm{mol}$ was computed using thermodynamic equilibrium constant $\left(\mathrm{K}_{\mathrm{C}}\right)$ by equation 3 :

$$
\Delta \mathrm{G}^{0}=-\mathrm{RT} \ln \mathrm{K}_{\mathrm{C}}
$$

Where, $\mathrm{R}$ is ideal gas constant $(8.314 \mathrm{~J} / \mathrm{mol} \mathrm{K}), \mathrm{T}$ is temperature in $\mathrm{K}$

The $\mathrm{K}_{\mathrm{C}}$ is related to $\mathrm{C}_{\partial}$ and $\mathrm{C}_{\mathrm{e}}$ by the equation 4 :

$$
\mathrm{K}_{\mathrm{C}=} \mathrm{C}_{\partial} / \mathrm{C}_{\mathrm{e}}
$$

Where, $\mathrm{C}_{\partial}$ is milligram of Adsorbate adsorbed per liter $(\mathrm{mg} / \mathrm{L})$ and $\mathrm{C}_{\mathrm{e}}$ is the equilibrium concentration of solution in milligram per liter $(\mathrm{mg} / \mathrm{L})$.

$\mathrm{C}_{\partial}$ was calculated on the basis of following relation given in equation 5: 


$$
\mathrm{C}_{\partial}=\mathrm{C}_{\mathrm{i}}-\mathrm{C}_{\mathrm{e}}
$$

Where, $C_{i}$ is the initial concentration of solution in milligram per liter $(\mathrm{mg} / \mathrm{L})$ and $\mathrm{C}_{\mathrm{e}}$ is is the equilibrium concentration of solution in milligram per liter(mg/L).

According to Van't Hoff equation $\Delta \mathrm{G}^{0}$ is related to $\Delta \mathrm{H}^{0}$ and $\Delta \mathrm{S}^{0}$ by the relation presented in equation 6:

$$
\ln \mathrm{K}_{\mathrm{C}}=-\frac{\Delta \mathrm{G}^{0}}{\mathrm{RT}}=-\frac{\Delta \mathrm{H}^{0}}{\mathrm{RT}}+\frac{\Delta \mathrm{S}^{0}}{\mathrm{R}}
$$

The values of $\Delta \mathrm{H}^{0}$ and $\Delta \mathrm{S}^{0}$ were calculated from the slope and intercept of the plot of $\ln \mathrm{K}_{\mathrm{C}}$ versus $1 / \mathrm{T}[32,33]$.

The adsorbent dose optimization study was carried out by altering dose from 0.25 to 2.75 gram keeping $\mathrm{pH}$, agitation speed and temperature all at optimum condition. The adsorption capacity ( $\mathrm{q}_{\mathrm{e}}$ milligram per gram) was determined by the equation 7 :

$$
q_{e}=V \frac{\left(C_{i}-C_{e}\right)}{w}
$$

Where, $C_{i}$ is initial concentration of heavy metals ions and $\mathrm{Ce}$ is final or equilibrium concentration of heavy metal ion in milligram per liter, $\mathrm{V}$ is the volume of the solution in liter and $\mathrm{W}$ is the mass of the Adsorbate in gram $[34,35]$.

Eventually at the end of study the contact time was optimized, carrying out the adsorption at achieved optimum conditions.

\subsection{Adsorbent Characterization}

\section{Results And Discussions}

The result of physical analysis of prepared adsorbent is shown in Table 2. The yield of adsorbent on dry raw husk mass basis was $31.73 \%$. The bulk density of adsorbent was found to be 0.6085 gram per cubic centimeter $\left(\mathrm{g} / \mathrm{cm}^{3}\right)$ and electrical conductivity (specific conductance) 276.75 milli Siemens per meter $(\mathrm{mS} / \mathrm{m})$. The particle size data shows that $\mathrm{Ad}_{1}$ had majority of particles between 210 to 250 micron.

Table 2: Physical Characteristics of Adsorbent ( $\left.\operatorname{Ad}_{1}\right)$

\begin{tabular}{|l|c|}
\hline \multicolumn{1}{|c|}{ Parameter } & Result \\
\hline Yield (\%) & $31.73 \pm 0.32$ \\
\hline Bulk density in $\mathrm{g} / \mathrm{cm}^{3}$ & $0.6085 \pm 0.0$ \\
\hline Conductivity $(\mathrm{mS} / \mathrm{m})$ & 276.75 \\
\hline Particle size & $51.84 \%$ \\
\hline \multicolumn{2}{|c|}{$210-250$ micron } \\
\hline $180-210$ micron & $9.82 \%$ \\
\hline $150-180$ micron & $38.34 \%$ \\
\hline
\end{tabular}

Values are Mean $( \pm$ SEM) of 3 determinations

Table 3 is representing the chemical characteristics of adsorbent $\mathrm{Ad}_{1}$. The adsorbent had $4.54 \%$ moisture, $5.16 \%$ ash. The water soluble content with adsorbent was found to $0.52 \%$. The calorific value of adsorbent was 7047.94 Calories per gram $(\mathrm{Cal} / \mathrm{g})$. The $\mathrm{pH}$ of adsorbent solution as measured with Deluxe (EI) $\mathrm{pH}$ meter was observed to be 7.71 .

Table 3: Chemical Characteristics of Adsorbent $\mathbf{A d}_{1}$

\begin{tabular}{|l|c|}
\hline \multicolumn{1}{|c|}{ Parameter } & Result \\
\hline Moisture (\%) & $4.54 \pm 0.04$ \\
\hline Ash (\%) & $5.16 \pm 0.10$ \\
\hline Water soluble content (\%) & $0.52 \pm 0.02$ \\
\hline Calorific value (Cal/g) & $7047.94 \pm 2.92$ \\
\hline $\mathrm{pH}$ & $7.71 \pm 0.01$ \\
\hline
\end{tabular}

Values are Mean ( \pm SEM) of 3 determinations 
The traces of some elements found with $\mathrm{Ad}_{1}$ are given in Table 4. The result predicted minerals responsible for ash in adsorbent to be of Magnesium (Mg), Calcium (Ca), Sodium (Na), Ferrous (Fe), Manganese (Mn), Zinc ( $\mathrm{Zn})$, Copper $(\mathrm{Cu})$ and Lead $(\mathrm{Pb})$.

Table 4: Trace Element Analysis of Adsorbent $\mathrm{Ad}_{1}$

\begin{tabular}{|l|c|c|c|c|c|c|c|c|}
\hline Element & $\mathrm{Mg}$ & $\mathrm{Ca}$ & $\mathrm{Na}$ & $\mathrm{Fe}$ & $\mathrm{Zn}$ & $\mathrm{Cu}$ & $\mathrm{Mn}$ & $\mathrm{Pb}$ \\
\hline Result (ppm) & 3503.04 & 1423.61 & 1169.62 & 70.41 & 57.17 & 19.66 & 14.75 & 6.23 \\
\hline
\end{tabular}

The XRD pattern of adsorbent is represented in Fig. 1. The peak obtained for adsorbent was compare with the standard peak for carbon and found matching. The result thus confirms that after carbonization adsorbent raw tur dal husk was transformed to adsorbent carbon. The XRD result also showed the nature of crystals in adsorbent as hexagonal and a mixture of $29.6 \%$ crystalline and $70.4 \%$ amorphous crystals.

Fig. 2 and 3 is showing the scanning electron microscope pictures of raw tur dal husk and adsorbent $\mathrm{Ad}_{1}$. It is clear from the SEM images that raw husk had very less pores of small sizes whereas carbonized form of husk $\left(\mathrm{Ad}_{1}\right)$ had many pores of bigger sizes. The porous structure of $\mathrm{Ad}_{1}$ explains why it was more suitable for adsorption of metals ion as compare to raw husk.

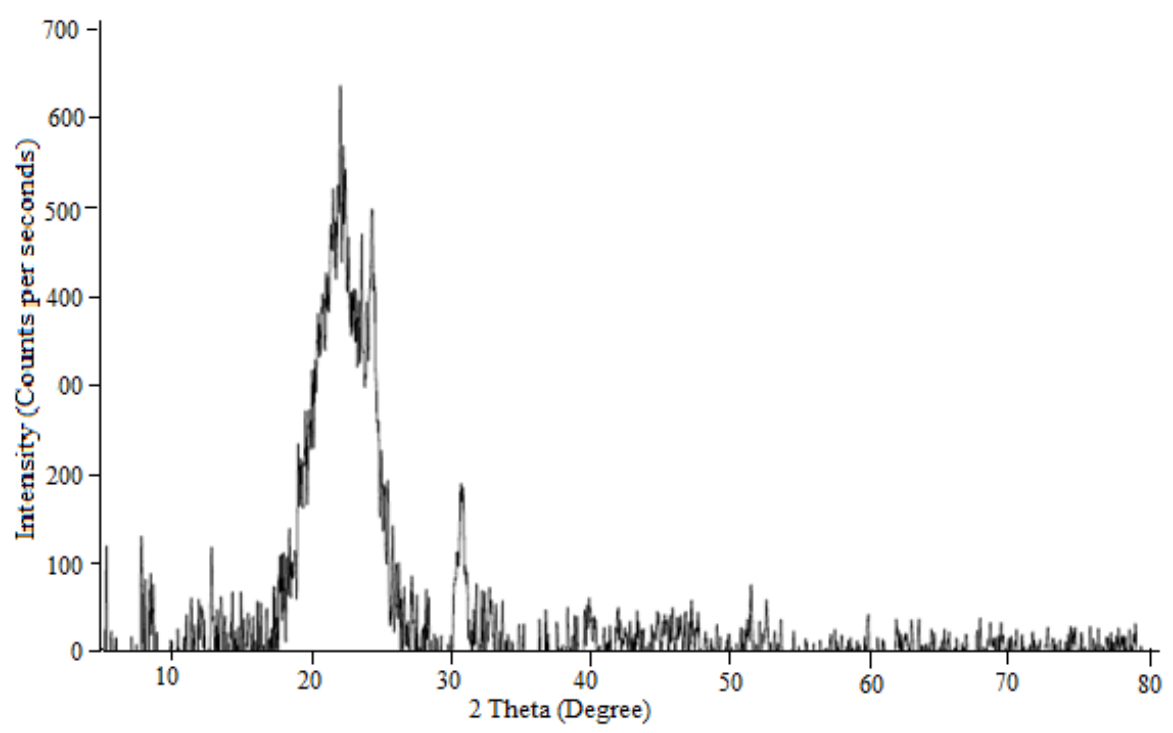

Figure 1: XRD pattern of $\mathrm{Ad}_{1}$

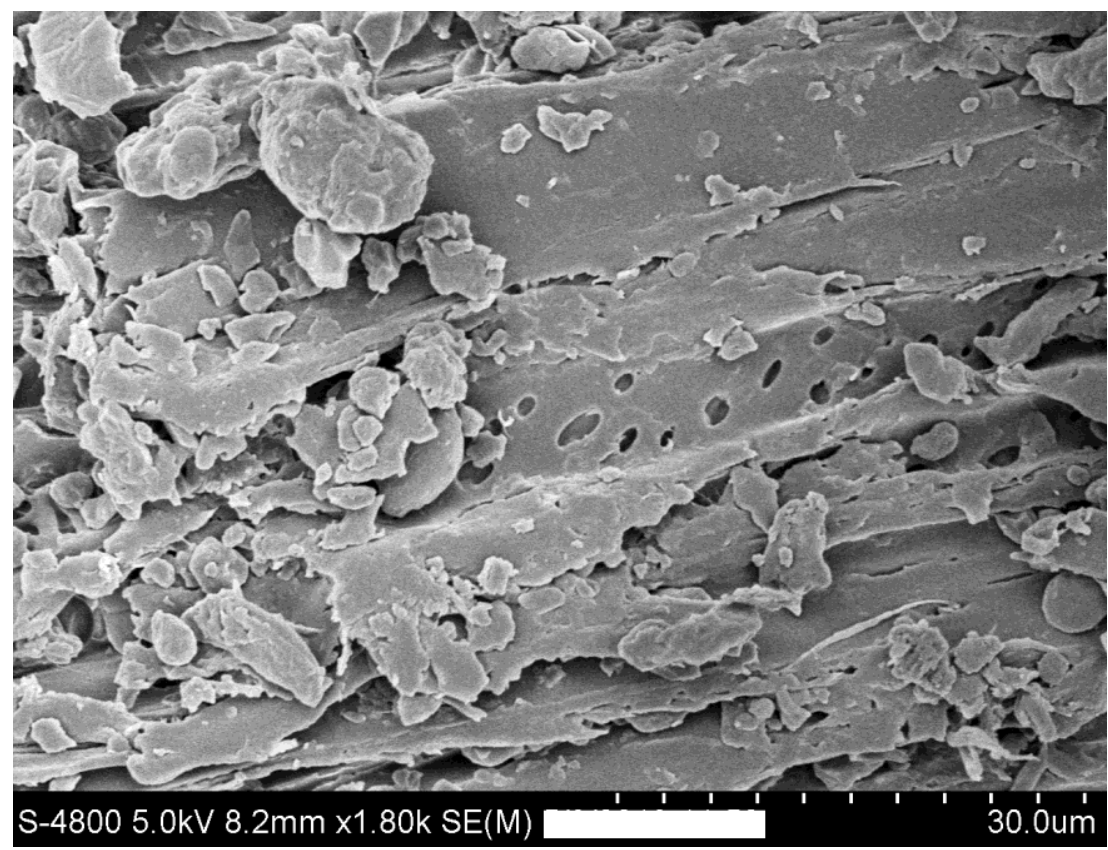

Figure 2: Scanning electron microscope image of raw tur dal husk 


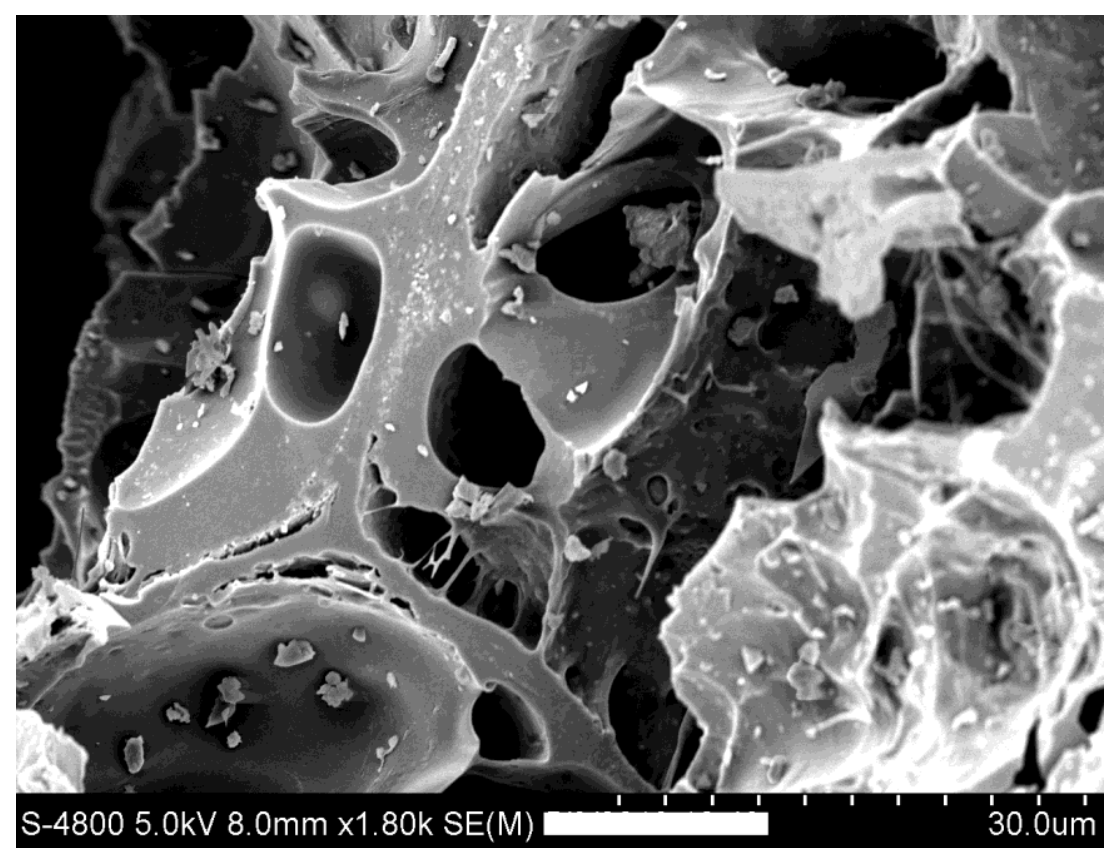

Figure 3: Scanning electron microscope image of $\mathrm{Ad}_{1}$

\subsection{Initial Adsorption Trial}

The findings of adsorption study of $\mathrm{Cu}$ ion by developed adsorbent from tur dal husk in without optimization of adsorption condition is shown in Table 5. The result of first trial revel removal of $\mathrm{Cu}$ ion from it's solution of $100 \mathrm{ppm}$ with $0.1 \mathrm{~g}$ adsorbent was low $(8.3 \%)$. The second trial was therefore planned with $0.1 \mathrm{~g}$ adsorbent but reducing the initial concentration of $\mathrm{Cu}$ solution to $50 \mathrm{ppm}$. The result of second trial in term of \% removal was also not satisfactory as only $16.4 \%$ removal of $\mathrm{Cu}$ ion was observed. The third trail was carried out keeping initial concentration of $\mathrm{Cu}$ ion solution same $(50 \mathrm{ppm})$ and increasing the adsorbent dose $(0.25 \&$ $0.5 \mathrm{gm})$. The \% removal was $28.1 \%$ and $36.8 \%$ with adsorbent dose 0.25 and $0.5 \mathrm{~g}$ respectively. According to Indian Environment (Protection) Rule the permissible maximum limits of copper in industrial effluent for discharge in inland surface water, public sewers and in marine costal area is maximum $3.0 \mathrm{ppm}$ [36]. In order to utilize the developed adsorbent for the industrial effluent treatment, there was need to achieve more than $94 \%$ removal in the said planned experiments. Many researchers already have attempted to enhance the adsorption performance of metal adsorbent by optimization of adsorption condition and achieved drastic improvement in adsorption [37]. The optimization of adsorption conditions was therefore felt essential for improving the performance of adsorbent.

Table 5: Result of Initial Adsorption Trials

\begin{tabular}{|l|c|c|c|c|}
\hline Parameter & First Trial & Second Trial & \multicolumn{2}{|c|}{ Third Trial } \\
\cline { 3 - 5 } & & & $0.25 \mathrm{~g}$ & $2.5 \mathrm{hr}$. \\
\hline Equilibrium Time & $2.0 \mathrm{hr}$ & $1.5 \mathrm{hr}$. & $3.5 \mathrm{hr}$. \\
\hline $\begin{array}{l}\text { Residual } \mathrm{Cu} \text { ion concentration at } \\
\text { equilibrium }\end{array}$ & $90.6 \mathrm{ppm}$ & $41.5 \mathrm{ppm}$ & $31.2 \mathrm{ppm}$ \\
\hline$\%$ Removal of $\mathrm{Cu}$ ion & $8.3 \%$ & $16.4 \%$ & $28.1 \%$ & $36.8 \%$ \\
\hline
\end{tabular}

\subsection{Optimization of Adsorption Condition}

3.3.1 Effect of $\mathrm{pH}$ on Adsorption

Fig. 4 represents the effect of $\mathrm{pH}$ on Adsorption. The adsorption takes place by various mechanisms, and one of the import mechanisms is electrostatic force of attraction between metal ion (possessing positive charge) and adsorbent surface (carrying negative charge). The $\mathrm{pH}$ of the aqueous solution is considered to be most important parameter affecting adsorption of metal ion at the solid-liquid interfaces as changing the charges on the adsorbent surface. It was observed as the $\mathrm{pH}$ increased the $\%$ removal of $\mathrm{Cu}$ also increased linearly. The adsorption was very low at $\mathrm{pH} 2 \& 3$ (2.6 and $4.5 \%$ removal respectively) and then increased rapidly up to $\mathrm{pH} 6$ $(24.7 \%$ at $4,35.6 \%$ at $5 \& 41.7 \%$ at $6 \mathrm{pH})$. The concentration of $\mathrm{H}^{+}$in the solution and the surface charge of the adsorbent was the cause for the found effect. At acidic $\mathrm{pH}$, excess $\mathrm{H}^{+}$ions in the solution compete with the metal ion present in the solution for the adsorption sites of the adsorbent and prevent the metal ion from reaching the adsorption site. Thus at low $\mathrm{pH}$ adsorbent surface was more protonated and posses positive charge as the surface of adsorbent was completely covered with $\mathrm{H}^{+}$ions. The said condition was therefore not allowing 
adsorption of positively charged species in solution by adsorbent because of their repulsion by adsorbent surface. Retardation in diffusion of $\mathrm{Cu}$ species due to such repulsion was also the cause for the lower adsorption at lower $\mathrm{pH}$. As the $\mathrm{pH}$ of the system increased, the number of positively charged sites decreased and the number of negatively charged sites increased on the surface of adsorbents [38]. Due to said change in the surface charge of the adsorbent, as the $\mathrm{pH}$ increased beyond 3 the competition from the hydrogen ions decreased and the positively charged ions present in the solution $\left(\mathrm{Cu}^{2+}\right)$ now adsorbed at the negatively charged sites of the adsorbent. At $\mathrm{pH} 7$ and above the precipitation of $\mathrm{Cu}$ ion was observed due to formation of metal complex as hydroxide. The \% removal at $\mathrm{pH} 7$ and above was high (94.5\% at 7,97.0 at 8,98.2\% at 9 and 99.2 at 10 ) because of both the combine effect of precipitation as well as of adsorption mechanism. B.M.W.P.K Amarasinghe and R.A. Williams (2007) obtained the same type of result while adsorbing $\mathrm{Cu}$ ion with tea waste as low cost adsorbent. $\mathrm{H}$. Ye et al., 2012 also found the effect of $\mathrm{pH}$ in similar trend for removing $\mathrm{Cu}$ (II) from aqueous solution using modified rice husk [39]. Other researchers also received the same kind of result with adsorbent material coca shells, orange waste $[40,41]$. Even at $6.5 \mathrm{pH}$ very slight precipitation was observed. Therefore to support the removal of $\mathrm{Cu}$ ion only by adsorption and not by precipitation, the optimum $\mathrm{pH}$ for the adsorption was fixed at 6.0.

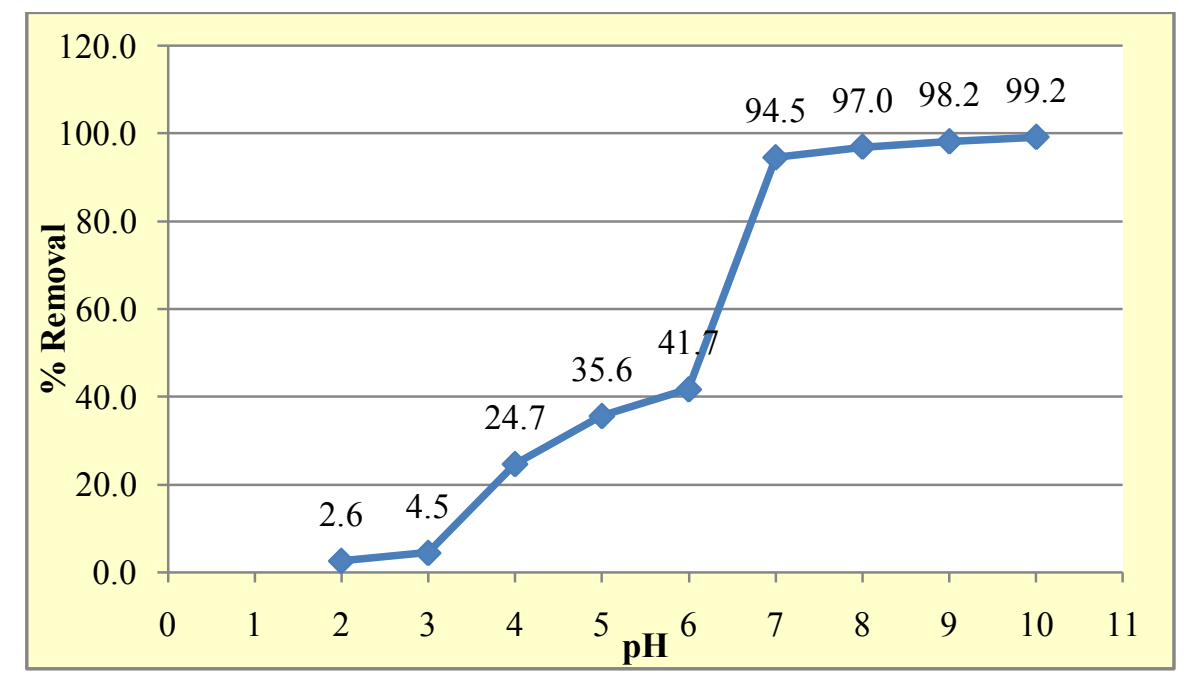

Figure 4: Effect of $\mathrm{pH}$ on $\mathrm{Cu}$ adsorption by $\mathrm{Ad}_{1}$

\subsubsection{Effect of Agitation on Adsorption}

The effect of agitation on $\mathrm{Cu}$ uptake is shown in Fig. 5. The data revel as the agitation speed increased the adsorption efficiency also increased until it reached peak value (41.1\% removal) and then further increase in agitation had no benefit on adsorption. It was observed, \% removal of $\mathrm{Cu}$ increased progressively as the agitation speed increased from 50 to $150 \mathrm{rpm}(36 \%, 39.5 \%$ \& $41.1 \%$ removal at $50,100 \& 150 \mathrm{rpm}$ respectively). The reason behind the same is mass transfer phenomenon which is generally observed during adsorption. The adsorbate molecules first migrate from the bulk of the solution towards the adsorbent surface, the diffusion of adsorbate then takes place through the boundary layer to the adsorbent surface. After this only the actual adsorption of adsorbate occur on adsorption site of adsorbent. The adsorption takes place not only on the surface of adsorbent, the adsorbate molecules further diffuse in the bulk of adsorbent and there also again the adsorption occur [42]. At lower agitation speeds, the fluid film around the adsorbate particle was thicker due to which the difficulty in crossing the boundary layer was faced by adsorbent particle, resulting low adsorption [43]. The justification of increase in adsorption due to increase in the agitation speed lies in the fact as the agitation speed increased the turbulence also increased and it overcame the boundary layer resistance and facilitate the migration of Adsorbate molecules from the bulk solution to the surface of adsorbent. Also as the rate of transfer of Adsorbate molecules toward the adsorption surface increased, in turn it forced the diffusion of adsorbate inside adsorbent mass. It is concluded as the agitation speed increase the adsorption also increase due to improvement in migration rate of adsorbate towards the adsorbent and the forcing of diffusion of adsorbate inside the adsorbent bulk. The findings of Y.C. Sharma et al. (1991) also agreed with result while using tamarind seed for adsorbing cadmium [44].However the adsorption was found to be low at $200 \mathrm{rpm}(40.7 \%$ removal)and $250 \mathrm{rpm}$ ( $40.3 \%$ removal) as compare to $150 \mathrm{rpm}$ ( $41.1 \%$ removal). The reason for the same may be the improper contact between $\mathrm{Cu}^{2+}$ ion and the binding site of $\mathrm{Ad}_{1}$. A.V. AjayKumar et al., 2009 had also received similar type of result when tried to remove various heavy metals $\left(\mathrm{Cd}^{2+}, \mathrm{Cu}^{2+}, \mathrm{N}^{2+} \mathrm{i}, \mathrm{Zn}^{2+}\right)$ using activated sludge [45]. As the shaking speed $150 \mathrm{rpm}$ was sufficient to ensure the availability of all the binding 
sites of the adsorbent for uptake of maximum $\mathrm{Cu}^{2+}$ ion present in solution, the optimized agitation speed was therefore selected as $150 \mathrm{rpm}$.

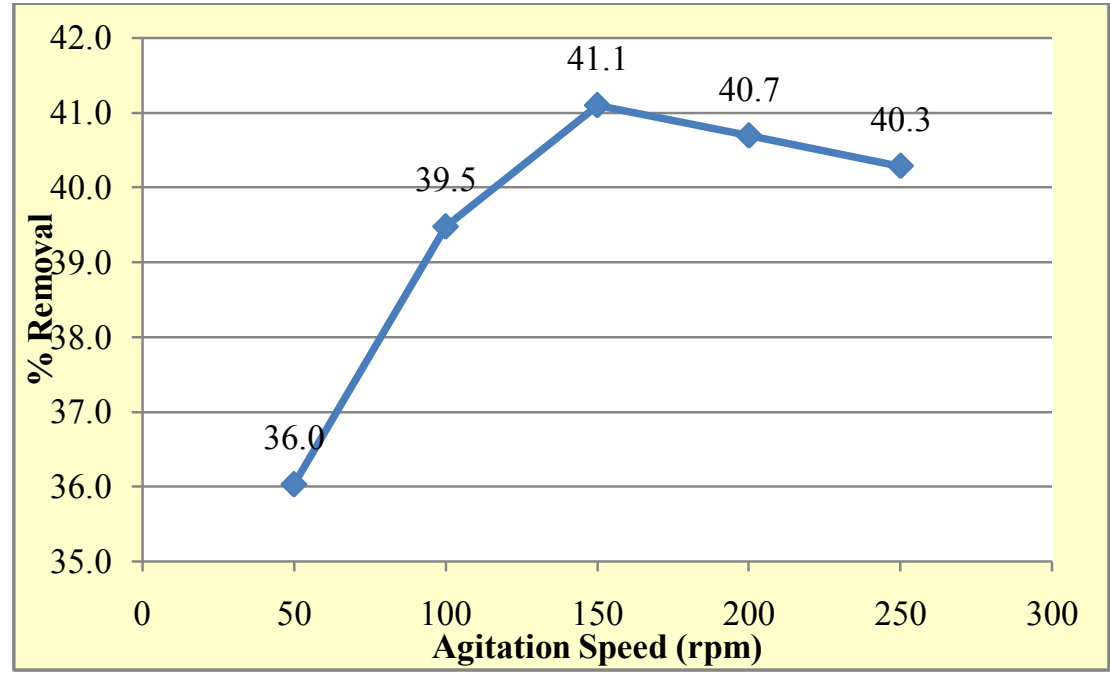

Figure 5: Effect of agitation speed on Cu adsorption by $\mathbf{A d}_{1}$

\subsubsection{Effect of Temperature on Adsorption}

The effect of temperature on $\mathrm{Cu}$ removal is given in Fig. 6. The \% removal of $\mathrm{Cu}$ was $35.8 \%, 38.3 \%$, $41.3 \%, 42.7 \%, 44.9 \%, 45.5 \%$ at $10,20,30,40,50$ and $60{ }^{\circ} \mathrm{C}$ respectively. The adsorption of $\mathrm{Cu}$ was observed to be facilitated by increase in temperature. It means the adsorption reaction was absorbing heat to occur. The adsorption of $\mathrm{Cu}$ by the adsorbent was considered endothermic in nature. The predicted cause for improvement in \% removal with increase in temperature may be due to the formation of new binding sites on and near the surface of $\mathrm{Ad}_{1}$ as a result of breaking of some internal bonds. Increase in the kinetic energy of adsorbate was also thought as the another possible reason for the increase in adsorption that facilitated diffusion of Adsorbate within pores of adsorbent [46]. Diffusion also increased due to decrease in viscosity of solution as a consequence of increasing temperature and enlargement of pore size. The similar result was obtained by S.H. Hasan et al., 2008 in an attempt to adsorb Cr(VI) by agricultural waste (maize bran) [47]. The increase in adsorption efficiency with increase in temperature was observed by X.S. Wang et al. (2010), while removing metal ion (chromium) with adsorbent carbon derived from wheat-residue [48].

S. Sun, and A. Wang (2006) had also received the same result of increase in adsorption with increase in temperature while removing $\mathrm{Cu}(\mathrm{II})$ ions using $\mathrm{N}$, O-carboxymethyl chitosan [49].The $60{ }^{\circ} \mathrm{C}$ temperature was thus optimized for the said adsorption.

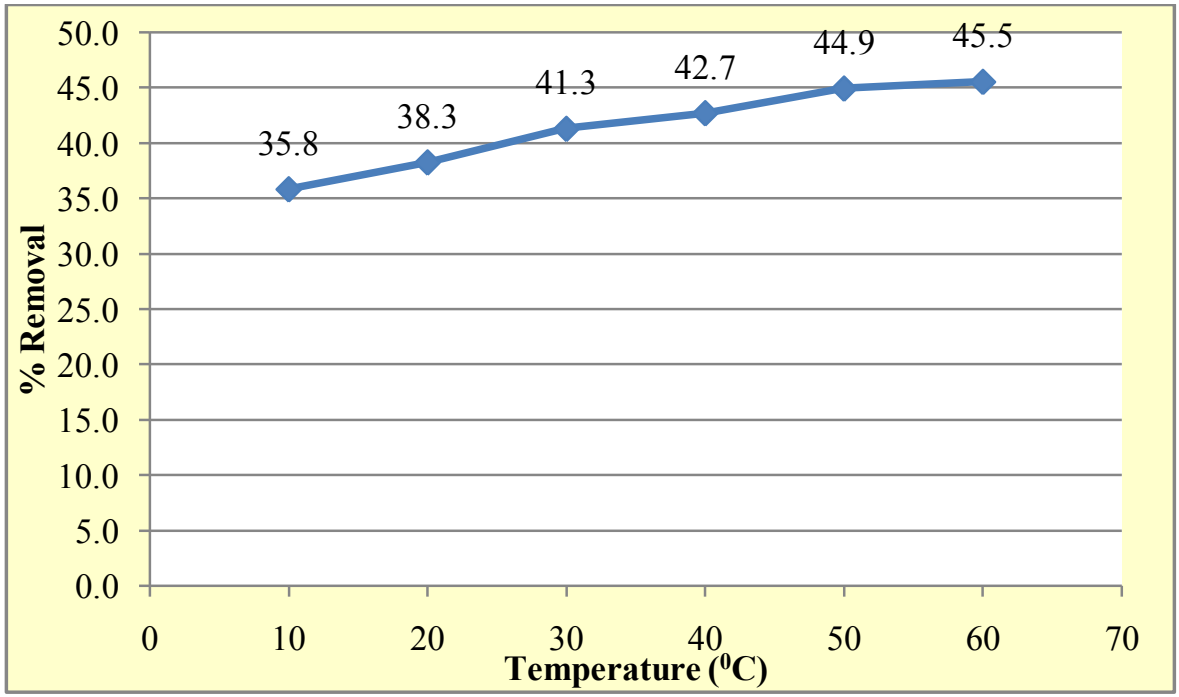

Figure 6: Effect of temperature on $\mathrm{Cu}$ adsorption by $\mathrm{Ad}_{1}$ 
The estimation of standard Gibb's free energy of adsorption at different temperature is shown in Table 6. The $\Delta \mathrm{G}^{0}$ was found to be1371.14, $1165.78,886.14,764.00,545.48$ and $426.78 \mathrm{~J} / \mathrm{mol}$ for the temperature 10 , 20, 30, 40, 50 and $60{ }^{\circ} \mathrm{C}$ respectively. The $\Delta \mathrm{G}^{0}$ was observed to be decreasing with increase in temperature but remain positive for all the temperature. The obtained positive values of $\Delta \mathrm{G}^{0}$ at all studied temperatures conclude that adsorption process was endergonic (non-spontaneous) [50]. The result is in accordance with the study done by G. Moussavi, and B. Barikbin (2010) where $\Delta \mathrm{G}^{0}$ obtained was positive during adsorption of $\mathrm{Cr}(\mathrm{VI})$ by pistachio hull powder.

Table 6: Standard Gibb's Free Energy of Adsorption at Different Temperature

\begin{tabular}{|c|c|c|c|c|c|c|c|c|}
\hline $\begin{array}{c}\text { Temperature } \\
\left({ }^{0} \mathrm{C}\right)\end{array}$ & $\begin{array}{c}\text { Temperature } \\
\text { T (K) }\end{array}$ & $1 / T$ & $\begin{array}{c}\text { Initial } \\
\text { Concentration } \\
\text { of } \mathbf{C u \text { solution }}\left(\mathrm{C}_{\mathrm{i}}\right) \\
(\mathrm{mg} / \mathrm{L}) \\
\end{array}$ & $\begin{array}{c}\text { Equilibrium } \\
\text { Concentration of } \\
\text { Cu solution } \\
\left(\mathbf{C}_{\mathrm{e}}\right)(\mathrm{mg} / \mathrm{L})\end{array}$ & $\begin{array}{c}C_{\partial}= \\
C_{i}-C_{e} \\
(\mathbf{m g} / L)\end{array}$ & $\begin{array}{c}\mathbf{K}_{\mathbf{C}}= \\
\mathbf{C}_{\partial} / \mathbf{C}_{\mathbf{e}}\end{array}$ & $\ln K_{C}$ & $\begin{array}{l}\Delta G^{0}= \\
-\mathbf{R T} \ln K_{\mathbf{C}} \\
\quad(\mathbf{J} / \mathbf{m o l})\end{array}$ \\
\hline 10 & 283 & 0.0035 & 49.40 & 31.7 & 17.7 & 0.5584 & -0.58 & 1371.14 \\
\hline 20 & 293 & 0.0034 & 49.40 & 30.5 & 18.9 & 0.6197 & -0.48 & 1165.78 \\
\hline 30 & 303 & 0.0033 & 49.40 & 29 & 20.4 & 0.7034 & -0.35 & 886.14 \\
\hline 40 & 313 & 0.0032 & 49.40 & 28.3 & 21.1 & 0.7456 & -0.29 & 764.00 \\
\hline 50 & 323 & 0.0031 & 49.40 & 27.2 & 22.2 & 0.8162 & -0.20 & 545.48 \\
\hline 60 & 333 & 0.0030 & 49.40 & 26.6 & 22.8 & 0.8571 & -0.15 & 426.78 \\
\hline
\end{tabular}

Fig.7 is the plot of $\ln K_{C}$ versus $1 / T$ for determining the values of $\Delta \mathrm{H}^{0}$ and $\Delta \mathrm{S}^{0}$. The value of $\ln K_{C}$ was found to decrease linearly with increase in value of $1 / \mathrm{T}$. The line had equation $\mathrm{y}=-819.2 \mathrm{x}+2.324$ with slope 819.2 and $y$-intercept 2.324. The data of line was found to fit satisfactory as coefficient of determination $\left(\mathrm{R}^{2}\right)$ was closer to unity (0.989). The slope of line and y-intercept was used in Van't Hoff equation to calculate $\Delta \mathrm{H}^{0}$ and $\Delta \mathrm{S}^{0}$ and is given in Table 7. The value of $\Delta \mathrm{H}^{0}$ and $\Delta \mathrm{S}^{0}$ was found to be $6810.82 \mathrm{~J} / \mathrm{mol}$ and $19.32 \mathrm{~J} / \mathrm{mol} \mathrm{K}$ respectively. Both $\Delta \mathrm{H}^{0}$ and $\Delta \mathrm{S}^{0}$ were found to be positive for the said adsorption. The positive value of $\Delta \mathrm{H}^{0}$ again confirms that the adsorption was endothermic. The positive value of $\Delta \mathrm{H}^{0}$ and $\Delta \mathrm{S}^{0}$ tells the adsorption reaction was unfavorable for enthalpy but favorable for entropy. The positive value of $\Delta S^{0}$ revel increased randomness at the solid/solution interface during adsorption and the system became more disordered through adsorption process. The similar finding(positive $\Delta \mathrm{H}^{0}$ and positive $\Delta \mathrm{S}^{0}$ ) was reported in a study of the adsorption of nitrate from aqueous solutions by activated carbons prepared from sugar beet bagasse activated chemically with $\mathrm{ZnCl}_{2}$ [51]. When adsorbing copper from aqueous solutions using watermelon shell, positive $\Delta \mathrm{H}^{0}$ and positive $\Delta \mathrm{S}^{0} \mathrm{Was}$ also observed by K. Banerjee et al., 2012 [52].

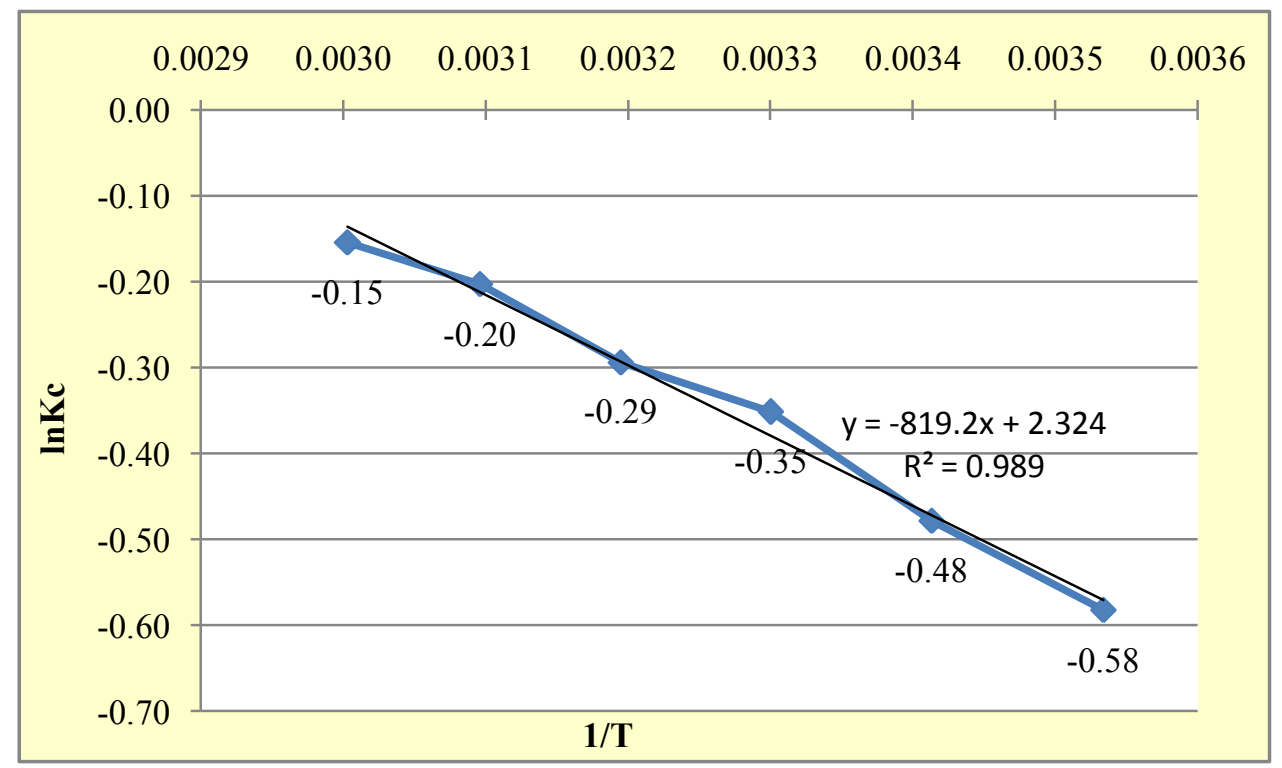

Figure 7: Plot of $\ln K_{C}$ versus 1/T

Table 7: Standard Enthalpy Change $\left(\Delta \mathrm{H}^{0}\right)$ and Entropy Change $\left(\Delta \mathrm{S}^{0}\right)$ of Adsorption

\begin{tabular}{|c|c|c|c|c|c|}
\hline $\begin{array}{c}\text { Van't Hoff Equation } \\
\ln \mathrm{K}_{\mathrm{C}}=-\frac{\Delta \mathrm{G}^{0}}{\mathrm{RT}}=-\frac{\Delta \mathrm{H}^{0}}{\mathrm{RT}}+\frac{\Delta \mathrm{S}^{0}}{\mathrm{R}}\end{array}$ & $\begin{array}{c}\text { Equation of line with Corelation } \\
\text { coefficient }\end{array}$ & Slope & Y Intercept & $\Delta \mathrm{H}^{0}(\mathbf{J} / \mathbf{m o l})$ & $\begin{array}{c}\Delta \mathrm{S}^{0} \\
(\mathbf{J} / \mathbf{m o l ~ K})\end{array}$ \\
\cline { 3 - 6 } & $\mathrm{y}=-819.2 \mathrm{x}+2.324$ & -819.2 & 2.324 & 6810.82 & 19.32 \\
$\mathrm{R}^{2}=0.989$ & & & & \\
\hline
\end{tabular}




\subsubsection{Effect of Adsorbent Dose on Adsorption}

The effect of adsorbent dose on $\mathrm{Cu}$ adsorption is depicted in Fig.8. The \% removal was found to be $34.8,45.1,53.4,61.1,75.3,85.0,94.9$ and $100 \%$ for adsorbent dose $0.25,0.5,0.75,1.0,1.5,2.0,2.5$ and $2.75 \mathrm{~g}$ respectively. The adsorbent capacity of $3.4,2.2,1.8,1.51 .2,1.1,0.9,0.9 \mathrm{mg}$ of $\mathrm{Cu}$ per $\mathrm{g}$ of adsorbent was observed for adsorbent dose $0.25,0.5,0.75,1.0,1.5,2.0,2.5$ and $2.75 \mathrm{~g}$ respectively. The \% removal of $\mathrm{Cu}$ was found to be increasing with increase dose of $\mathrm{Ad}_{1}$ whereas the adsorption capacity $\mathrm{q}_{\mathrm{e}}$ found to be decreasing with increasing dose of adsorbent. Earlier study by other researchers also confirms the same trend in \% removal and adsorption capacity as consequence of increase amount of adsorbent dose for the removal of adsorbate [53, 54].The \% removal increased with increasing level of adsorbent due to the availability of large surface area which increased more numbers of adsorption sites. It was observed that with $0.25 \mathrm{~g}$ the \% removal was $34.8 \%$ but when the adsorbent dose was doubled $(0.5 \mathrm{~g})$ the $\%$ removal obtained was not double, instead it was less (45.1\%). This less prominent adsorption which was also the cause for decrease in $\mathrm{q}_{\mathrm{e}}$ with increase in the adsorbent dose may be related with the fact as the blocking of some of the adsorption sites, non availability of adsorbent surface due to their masking with formed adsorbent agglomerates (M.N. Ibrahim Mohammed et al., 2010) and lengthening of diffusion path. The saturation of adsorption sites as adsorption proceeds with increasing dose of adsorbent was also the reason for the decrease in adsorption capacity. As minimum $2.75 \mathrm{~g}$ dose required for compete removal of $\mathrm{Cu}$ species from $50 \mathrm{ml}(50 \mathrm{ppm}) \mathrm{Cu}$ solution, it was considered optimum for said adsorption.

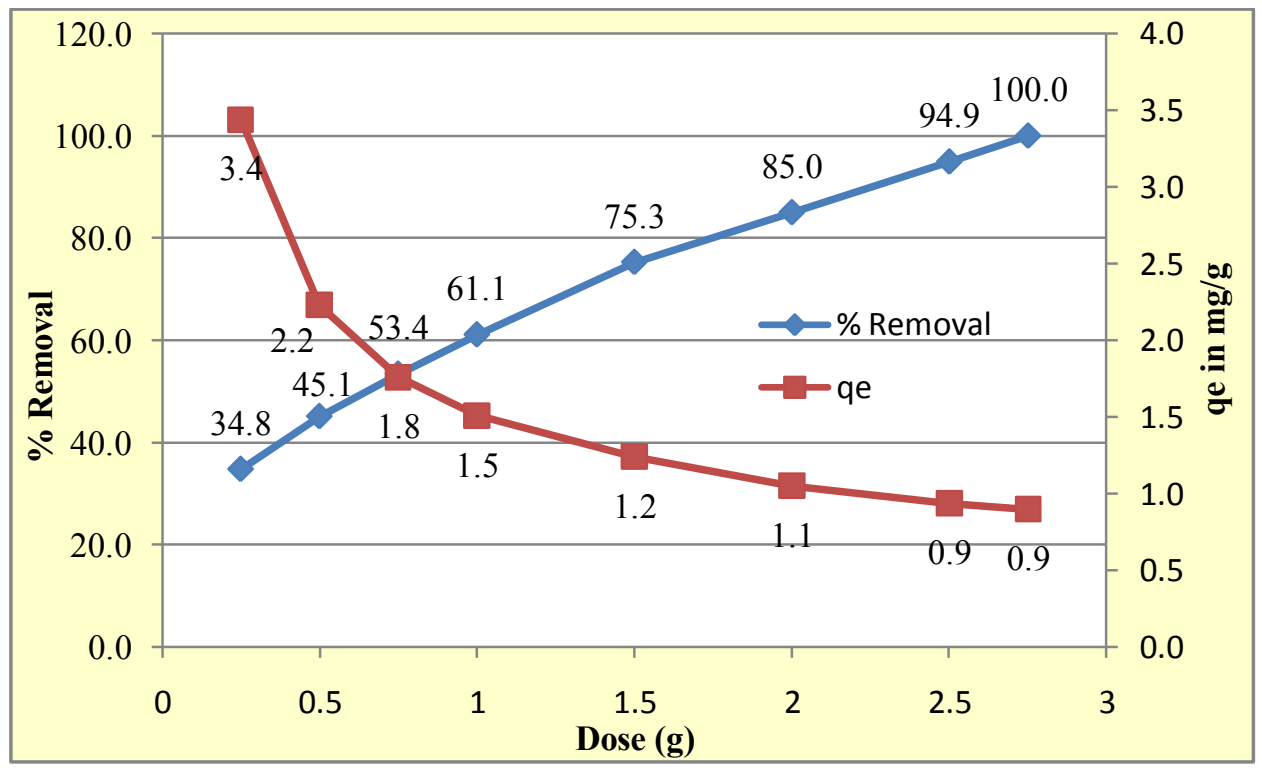

Figure 8: Effect of dose of $\mathrm{Ad}_{1}$ on $\mathrm{Cu}$ adsorption

\subsubsection{Contact Time Optimization}

The optimization of contact time was done at all the achieved optimized parameter for adsorption $(\mathrm{pH}$ 6, agitation speed $150 \mathrm{rpm}$, temperature $60{ }^{\circ} \mathrm{C}$ and adsorbent dose $2.75 \mathrm{~g}$ ) and in shown in Fig.9. The \% removal was found to be $85.4,90.3,93.9,96.4,98.8,100,100$ and $100 \%$ for contact time $0.5,1,1.5,2,2.5,3,3.5$ and 4 hr. respectively. The adsorption observed to be increasing with increasing contact time. Initially the removal of $\mathrm{Cu}$ was high due to the availability of large surface area. As the adsorption commenced with time there was exhaustion of adsorption sites with adsorbent. At his stage the phenomenon of migration of Adsorbate from the exterior to the interior sites of the adsorbent particles took the control of adsorption and the adsorption observed was less effective $[55,56]$. The result agrees with the findings of A.V. AjayKumar et al., 2009 while removing heavy metals on activated sludge. The other researchers also found the increase in adsorption with increasing contact time till the equilibrium time is attend [57]. The complete adsorption was achieved in $3 \mathrm{hr}$., which was a minimum time for $100 \%$ removal of $\mathrm{Cu}$. The contact time of $3 \mathrm{hr}$. was finalized as the optimum time for the considered adsorption. 


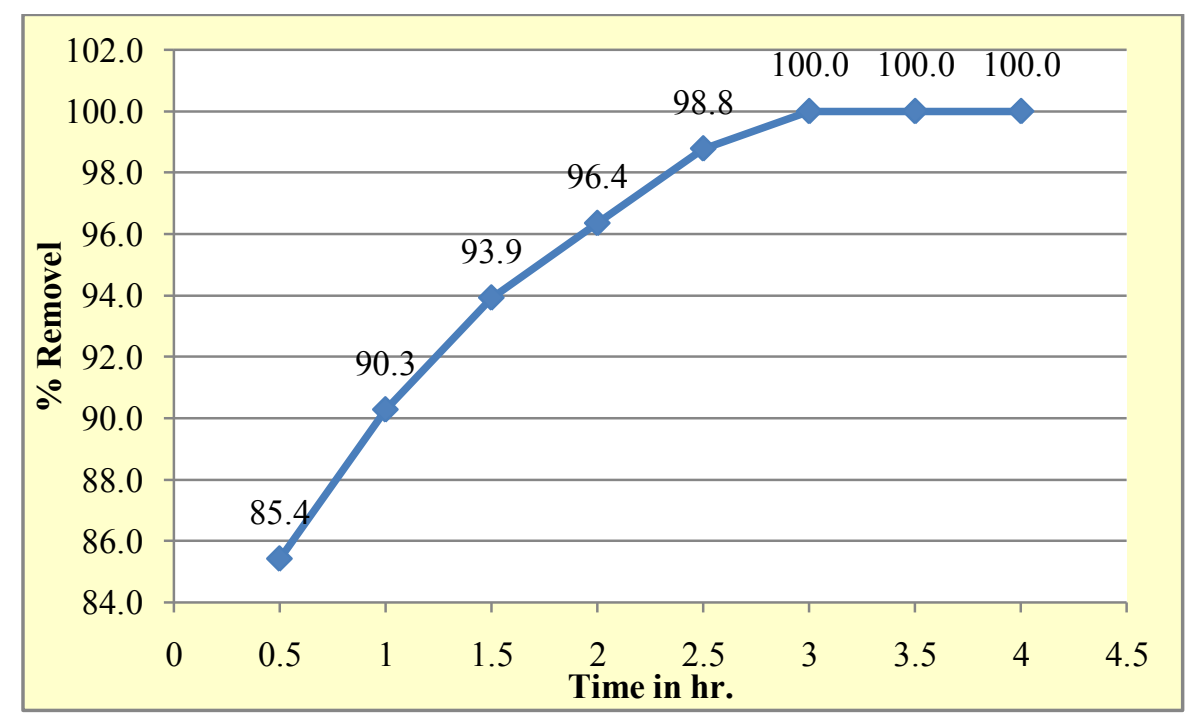

Figure 9: Effect of contact time on adsorption of $\mathrm{Cu}$ by $\mathrm{Ad}_{1}$

\section{Conclusion}

The effective metal adsorbent can be prepared from tur dal (Cajuns Cajon) husks simply by their carbonization. The optimum condition required to remove complete $\mathrm{Cu}$ ions from $50 \mathrm{ml}, 50 \mathrm{ppm} \mathrm{Cu}$ solution using developed adsorption is $\mathrm{pH}$, agitation speed $150 \mathrm{rpm}$, temperature $60{ }^{\circ} \mathrm{C}$, adsorbent dose $2.75 \mathrm{~g}$ and contact time $3 \mathrm{hr}$. However the metal adsorption by the prepared adsorbent is endothermic in nature, nonspontaneous and increases randomness at the adsorption site. The findings of present the work may be useful in designing the process of waste water treatment for removing heavy metals particularly copper by adsorption.

\section{References}

[1] D. Sud, G. Mahajan, and M.P. Kaur. Agricultural waste material as potential adsorbent for sequestering heavy metal ions from aqueous solutions - A review. Bioresource Technology, 99(14), 2008, 6017-6027.

[2] S.P. Dubey and K, Gopal, Adsorption of chromium(VI) on low cost adsorbents derived from agricultural waste material: A comparative study, Journal of Hazardous Material, 145(3), 2007. 465-470.

[3] A. Bhatnagar, and M. Sillanpaa, Utilization of agro-industrial and municipal waste materials as potential adsorbents for water treatment-A review, Chemical Engineering Journal, 157(2-3), 210, 277-296.

[4] U. Garg, M.P., Kaur, G.K, Jawa, D. Sud, and V.K. Garg, Removal of cadmium (II) from aqueous solutions by adsorption on agricultural waste biomass, Journals of Hazardous Materials, 154(1-3), 2008, 1149-1157.

[5] S.E. Bailey, T.J. Olin, R.M. Bricka, and D.D. Adrian, A review of potentially low-cost sorbents for heavy metals, Water Research, 33(11), 1999, 2469-2479

[6] Y. Nuhoglu, and E. Malkoc, Thermodynamic and kinetic studies for environmental friendly $\mathrm{Ni}$ (II) biosorption using waste pomace of olive oil factory, Bioresource Technology, 100(8), 2009, 2375-2380.

[7] S. Babel, and T.A. Kurniawan, Low-cost adsorbents for heavy metals uptake from contaminated water: a review, Journal of Hazardous Materials, 97(1-3), 2003, 219-243.

[8] A. Demirbas, Heavy metal adsorption onto agro-based waste materials: A review, Journal of Hazardous Materials, 157(2-3), 2008, 220-229.

[9] J. Anandkumara, and B. Mandalb, Removal of $\mathrm{Cr}(\mathrm{VI})$ from aqueous solution using Bael fruit (Aegle marmelos correa) shell as an adsorbent, Journal of Hazardous Materials 168(2-3), 2009, 633-640.

[10] D. Sud, and G. Mahajan, M.P. Kaur, Agricultural waste material as potential adsorbent for sequestering heavy metal ions from aqueous solutions - A review, Bioresource Technology 99(14), 2008, 6017-6027.

[11] A.A. Abia, M. Horsfall Jr., and O. Didi, The use of chemically modified and unmodified cassava waste for the removal of $\mathrm{Cd}, \mathrm{Cu}$ and $\mathrm{Zn}$ ions from aqueous solution, Bioresource Technology, 90(3), 2003, 345-348.

[12] J. Acharya, J.N. Sahu, C.R. Mohanty, B.C. Meikap, Removal of lead (II) from wastewater by activated carbon developed from Tamarind wood by zinc chloride activation, Chemical Engineering Journal, 149(1), 2009, 249-262.

[13] S.S. Ahluwalia and D. Goyal, Removal of heavy metals by waste tea leaves from aqueous solution, Engineering in Life Sciences, 5(2), 2005, 158-162.

[14] G. Annadurai, H.S., Juang, and D.J. Lee, Adsorption of heavy metal from water using banana and orange peels, Water Science and Technology, 47(1), 2002, 185-190.

[15] N. Fiol, I., Villaescusa, M., Martinez, N., Miralles, J., Poch, and J. Serarols, Sorption of Pb(II), Ni(II), Cu(II) and Cd(II) from aqueous solution by olive stone waste, Separation and Purification Technology, 50(1), 2006, 132-140.

[16] J. Kim, M. Sohn, D. Kim, S. Sohn, and Y. Kwon, Production of granular activated carbon from waste walnut shell and its adsorption characteristics for Cu2+ ion, Journal of Hazardous Materials, 85(3), 2001, 301-315.

[17] W.E. Marshall, L.H. Wartelle, D.E. Boler, M.M. Johns, and C.A. Toles, Enhanced metal adsorption by soybean hulls modified with citric acid, Bioresource Technology, 69(3), 1999. 263-268.

[18] U.K. Garg, M.P. Kaur, V.K. Garg, and D. Sud, Removal of Nickel(II) from aqueous solution by adsorption on agricultural waste biomass using a response surface methodological approach, Bioresource Technology, 2008, 99(5), 1325-31.

[19] B.M.W.P.K Amarasinghe and R.A. Williams, Tea waste as a low cost adsorbent for the removal of $\mathrm{Cu}$ and $\mathrm{Pb}$ from wastewater, Chemical Engineering Journal 132(1-3), 2007, 299-309. 
[20] S. Ibrahim, S. Wang, and H.M. Ang, Removal of emulsified oil from oily wastewater using agricultural waste barley straw, Biochemical Engineering Journal, 49(1), 2010, 78-83.

[21] P.J.M Carrott. Suhas, and M.M.L., Ribeiro Carrott, Lignin - from natural adsorbent to activated carbon: A review, Bioresource Technology, 98(12), 2007, 2301-2312.

[22] N. Ahalya, R.D. Kanamadi and T.V. Ramachandra, Cr (VI) and Fe (III) removal using Cajanus cajan husk. Journal of Environmental Biology, 28(4), 2007, 765-769.

[23] M. Rafatullah, O. Sulaiman, R. Hashim, and A. Ahmad, Adsorption of methylene blue on low-cost adsorbents: A review, Journal of Hazardous Materials, 177(1-3), 2010, 70-80.

[24] G. Crini, Non-conventional low-cost adsorbents for dye removal: A review, Biosource technology, 97(9), 2006, 1061-1085

[25] A. Saeed, and M. Iqbal, Bioremoval of Cd from aqueous solution by black gram husk (Cicer arientinum), Water Research, 37(14), 2003, 3472-3480.

[26] N. Ahaly, R.D. Kanamadi, and T.V. Ramachandra, Biosorption of chromium (VI) from aqueous solutions by the husk of Bengal gram (Cicer arientinum), Electronic Journal of Biotechnology, 8(3), 2005, 258-264.

[27] E.-S.Z. El-Ashtoukhya, N.K.. Amina, and O. Abdelwahabb, Removal of lead (II) and copper (II) from aqueous solution using pomegranate peels as a new absorbent, Desalination, 223(1-3), 2008, 162-173.

[28] CEFIC (European Council of Chemical Manufacturers Federation/ European Chemical Industry Council), Test methods for activated carbon, 1986, 9-43.

[29] Bureau of Indian Standards IS 877: 1989, Activated carbons, powdered and granular- Methods of sampling and test (Second Revision), 1989, 1-7.

[30] Bureau of Indian Standards IS 14767: 2000, Determination of specific electrical conductivity of soils-Method of test, 2000, 1-4.

[31] M.N. Ibrahim Mohammed, W.S Nagh Wan, M.S. Norliyana, W.R. Daud, M. Rafatullah, O. Sulaiman, and R. Hashim, A novel agricultural waste adsorbent for the removal of lead (II) ions from aqueous solutions, Journal of Hazardous Materials, 182(1-3), 2010, 377-385.

[32] S. Liang, X. Guo, N. Feng, and Q. Tian, Isotherms, kinetics and thermodynamic studies of adsorption of Cu2+ from aqueous solutions by $\mathrm{Mg} 2+/ \mathrm{K}+$ type orange peel adsorbents, Journal of Hazardous Materials, 174(1-3), 2010, 756-762.

[33] Y. Nuhoglu, and E. Malkoc, Thermodynamic and kinetic studies for environmentaly friendly Ni(II) biosorption using waste pomace of olive oil factory, Bioresource Technology, 100(8), 2009, 2375-2380.

[34] S.N. Dash, and R. Murthy.Ch.V, Preparation of Carbonaceous Heavy Metal Adsorbent from Shorea RobustaLeaf Litter Using Phosphoric Acid Impregnation, International Journal of Environmental Science, 1(3),2010, 296-313.

[35] F. Banat, S. Al-Asheh, and L. Al-Makhadmeh, Evaluation of the use of raw and activated date pits as potential adsorbents for dye containing waters, Process Biochemistry, 39(2), 193-202.

[36] Environment (Protection) Rules, General standards for discharge of environmental pollutants, $1986,5$.

[37] S.M. Nomanbhay and K. Palanisamy, Removal of heavy metal from industrial wastewater using chitosan coated oil palm shell charcoal, Electronic Journal of Biotechnology, 8(1), 2005, 43-53.

[38] F.Y. Wang, H. Wang, and J.W. Ma, Adsorption of cadmium (II) ions from aqueous solution by a new low-cost adsorbent-Bamboo charcoal, Journal of Hazardous Materials, 177(1-3), 2010, 300-306.

[39] H. Ye, L. Zhang, B. Zhang, G. Wu, and D. Du, Adsorptive removal of Cu(II) from aqueous solution using modified rice husk. International Journal of Engineering Research and Applications (IJERA), 2(2),2012, 855-863.

[40] N. Meunier, J. Laroulandie, J.F. Blais, and R.D.Tyagi, Lead removal from acidic solutions by sorption on coca shells: effect of some parameters, Journal of Environmental Engineering, 129(8), 2003, 693-698.

[41] R.P. Dhakal, K.N. Ghimire, and K.. Inoue, Adsorptive separation of heavy metal from an aquatic environment using orange waste, Hydromettalurgy 79, 2005, 182-190.

[42] K. Banerjee, S.T. Ramesh, R. Gandhimathi, P.V. Nidheesh, and K.S. Bharathi, A novel agricultural waste adsorbent, watermelon shell for the removal of copper from aqueous solutions, Iranica Journal of Energy \& Environment 3(2),2012, $143-156$.

[43] G.O. EI-Sayed, H.M. Aly, S.H.M. Hussein, Removal of acrylic dye blue-5g from aqueous solution by adsorption on activated carbon prepared from maize cops, International Journal in Chemistry and Environment, 1(2), 2011, 132-140.

[44] Y.C. Sharma, G. Prasad, and D.C. Rupainwar, Adsorption of Cd onto tamarind seed, International Journal of Environmental Studies,37, 1991, 183-191.

[45] A.V. AjayKumar, N.A. Darwish, and N. Hilal, Study of various parameters in the biosorption of heavy metals on activated sludge, World Applied Sciences Journal, 5, 2009, 32-40.

[46] G. Moussavi, and B. Barikbin, Biosorption of chromium(VI) from industrial wastewater onto pistachio hull waste biomass, Chemical Engineering Journal, 162(3), 2010, 893-900.

[47] S.H. Hasan, K.K. Singh, O. Prakash, M. Talat, and Y.S. Hoc, Removal of Cr(VI) from aqueous solutions using agricultural waste 'maize bran', Journal of Hazardous Materials, 152(1), 2008, 356-365.

[48] X.S. Wang, L.F. Chen, F.Y. Li, K.L. Chen, W.Y. Wan, and Y.J. Tang, Removal of Cr (VI) with wheat-residue derived black carbon: reaction mechanism and adsorption performance, Journal of Hazardous Materials, 175(1-3), 2010, 816-822.

[49] S. Sun, and A. Wang, Adsorption kinetics of $\mathrm{Cu}(\mathrm{II})$ ions using N, O-carboxymethyl chitosan, Journal of Hazardous Materials, 131(1-3), 2006., 103-111.

[50] I.A.W. Tan, A.L. Ahmad, and B.H. Hameed, Adsorption isotherms, kinetics, thermodynamics and desorption studies of 2,4,6trichlorophenol on oil palm empty fruit bunch-based activated carbon, Journal of Hazardous Materials, 164(2), 2009, 473-482.

[51] H. Demiral, and G. Gunduzoglu, Removal of nitrate from aqueous solutions by activated carbon prepared from sugar beet bagasse, Bioresource Technology, 101(6),2010, 1675-1680.

[52] K. Banerjee, S.T. Ramesh, R. Gandhimathi, P.V. Nidheesh, and K.S. Bharathi, A novel agricultural waste adsorbent, watermelon shell for the removal of copper from aqueous solutions, Iranica Journal of Energy and Environment, 3(2),2012, $143-156$.

[53] S. Gupta, and B.V. Babu, Removal of toxic metal Cr(VI) from aqueous solutions using sawdust as adsorbent: Equilibrium, kinetics and regeneration studies, Chemical Engineering Journal, 150(2-3), 2009, 352-365.

[54] M. Bansala, U. Garg, D. Singh, and V.K. Garg, Removal of Cr(VI) from aqueous solutions using pre-consumer processing agricultural waste: A case study of rice husk, Journal of Hazardous Materials, 162(1),2009, 312-320.

[55] A. Ahmad, B.M. Siddique, M.H., Ibrahima, M. Rafatullah, O. Sulaimanb, and Y.Y. Chiia, Removal of Cu(II) and Pb(II) ions from aqueous solutions by adsorption on sawdust of Meranti wood, Desalination, 250, 2009, 300-310.

[56] S. Arivoli, V. Nandhakumar, S. Saravanan, and S. Nagarajan, Adsorption dynamics of copper ion by low Cost activated carbon, The Arabian Journal for Science and Engineering, 34(1 A),2009, 1-12.

[57] K.L. Dorris, B. Yu, Y. Zhang, A. Shukla, and S.S. Shukla, The removal of heavy metal from aqueous solutions by sawdust adsorption-removal of copper., Journal of Hazardous Materials, 80(1-3), 2000, 33-42. 